\title{
Trophic level and position of Pterygoplichthys pardalis in Ciliwung River (Jakarta, Indonesia) ecosystem based on the gut content analysis
}

\author{
DEWI ELFIDASARI ${ }^{1, v}$, FAHMA WIJAYANTI ${ }^{2, v v}$, AFIFATUS SHOLIHAH ${ }^{2}$ \\ ${ }^{1}$ Department of Biology, Faculty of Science and Technology, Universitas Al Azhar Indonesia. Komplek Masjid Agung Al Azhar, Jl. Sisingamangaraja, \\ Kebayoran Baru, Jakarta 12110, Indonesia. Tel.: +62-21-72792753; Fax.: +62-21-7244767, `email: d_elfidasari@uai.ac.id \\ ${ }^{2}$ Department of Biology, Faculty of Science and Technology, Universitas Islam Negeri Syarif Hidayatullah Jakarta. Jl. Ir. H. Djuanda No. 95, Ciputat, \\ Tangerang Selatan 15412, Banten, Indonesia. Tel.: +62-21-7401925, ^vemail: fahmawijaya@yahoo.com
}

Manuscript received: 3 April 2020. Revision accepted: 31 May 2020

\begin{abstract}
Elfidasari D, Wijayanti F, Sholihah A. 2020. Trophic level and Position of Pterygoplichthys pardalis in Ciliwung River (Jakarta, Indonesia) ecosystem based on the gut content analysis. Biodiversitas 21: 2862-2870. The trophic level of an organism describes its sequence of natural diet visible to the food chain along with its ecosystem. This is also related to the type of diet composition and food fraction obtained by analyzing its gut content. The Pterygoplichthys pardalis from Ciliwung River show the diversity of the natural diet. The aims of this study is to determine the trophic level and position of $P$. pardalis in the Ciliwung River ecosystem based on gut content analysis using the purposive sampling method. Data were obtained from a total of 30 fishes from the Kalibata and Cawang areas through observations. The fishes were dissected, and gut contents were observed using a light microscope, with observations repeated 5 times of each sample. Data analysis includes relative length of gut, Index of Preponderance, area of the diet niche, niche area, niche overlap, and trophic level of an organism. The results showed that $P$. pardalis in Ciliwung River is at trophic level II, and included as herbivores $(2.00<$ troph < 2.90) that consist of Bacillariophyta $(82.03 \%)$, Chlorophyta $(12.7 \%)$, Cyanophyta (3.74\%), Euglenophyta (1.19\%), Amoebozoa (0.28\%), and Dinoflagellata (0.68\%).
\end{abstract}

Keywords: Ciliwung River, gut content, natural diets, Pterygoplichthys pardalis, trophic level

\section{INTRODUCTION}

Pterygoplichthys pardalis is an invasive species originating from Central and South America (Armbruster 2004). It migrated into Indonesia through the ornamental fish trade route. $P$. pardalis has the ability to survive under highly polluted environment due to a gastric system modification which functions as an additional respiratory organ to survive in lack of dissolved oxygen areas (Armbruster 1998). Its strong adaptations led to the abundance of native fish in the Ciliwung River. The loss rate percentage of native fish diversity in the river reached $92.5 \%$ from 1910 to 2010 . This is due to the presence of $P$. pardalis (Hadiaty 2011). However, the availability of food resources is one of the factors that influence the existence of fishes. Previous studies have also established that a correlation exists between the structure of the digestive apparatus and the feeding habits of fishes (Pereira et al. 2016; Lopez-Rodriguez et al. 2019; Manna et al. 2020).

The type of diet consumed is generally influenced or determined by the morphological character of fish (Delariva and Agostinho 2001; Mazzoni et al. 2010; Pound et al. 2011; Aguilar-Betancourt et al. 2017; Winkler et al. 2017). For instance, $P$. pardalis has a suction type of ventral mouth, which allows fish to scrape food from rough surfaces (Samat et al. 2016). The shape of its mouth and its position is an adaptation pattern that aids fishes to obtain food. The position of the $P$. pardalis mouth is inferior due to its downward direction, thereby making it possible to suck various types of food in the water base. It is also known as eaters of algae, invertebrates such as snails, detritus, and food at the bottom of the water (Mazzoni et al. 2010; Pound et al. 2011; Sharpe 2016).

Generally, members of the Loricariidae feed on diets consisting of plant fragment, zooplankton, arthropods, chlorophytes, bacillariophytes, cyanobacteria and cyanobacteria (Mazzoni et al. 2010; de Oliveira and Isaac 2013; Samat, et al. 2016; Tisasari et al. 2016; Manna et al. 2020). Pterygoplichthys sp. discovered in Sungai Langat, Malaysia, is known to eat algae, plants, and animal fragments (Samat et al. 2016). In addition, it relates to the availability of diet resources and the environmental state of the water. The trophic level of an animal is influenced by the composition of its diet and the trophic level of each food fraction of which data is obtained from analyzing its stomach contents (Zardo and Behr 2016; Carvalho et al. 2017; Zainordin and Hamid 2017; Lopez-Rodriguez et al. 2019).

Presently, no data explains the trophic level and position of Pterygoplichthys pardalis in its ecosystem in accordance with the type of natural diet contained in the river. Due to this reason, it is necessary to conduct research aimed at analyzing the trophic level of $P$. pardalis in the ecosystem of the Ciliwung River, Jakarta, Indonesia based on gut content analysis. Subsequently, information obtained from this research is useful and serves as a source of data needed to manage the Ciliwung River. 


\section{MATERIALS AND METHODS}

\section{Study area}

Sampling was carried out along the Ciliwung River from the Rindam Jaya Condet area to Bidara Cina Cawang, Jakarta, Indonesia. The analysis of Pterygoplichthys pardalis samples was conducted at the Ecology Laboratory at the Integrated Laboratory Center, Syarif Hidayatullah State Islamic University, Jakarta, Indonesia.

This research consists of three observations and sampling stations namely St1, St2, and St3. The coordinates are as follows: St1: $06.244053^{\circ} \mathrm{S}$ $106.862654^{\circ} \mathrm{E}, \mathrm{St} 2: 06.25830^{\circ} \mathrm{S}-106.86040^{\circ} \mathrm{E}$, and $\mathrm{St} 3$ : $06.28599^{\circ} \mathrm{S}-106.84717^{\circ} \mathrm{E}$ as shown in Figure 1.

The research conducted includes collecting 30 fishes samples, which were divided into 3 groups based on its size and length, namely large (34.0-41.5 cm), medium (26.4$33.9 \mathrm{~cm})$, and small fish group $(18.7-26.3 \mathrm{~cm})$.

\section{Procedures}

Sampling methods

The determination of the sampling point was done by using purposive sampling method, which is based on the presence of plecos in the Ciliwung River Condet area (coordinates: $06.244053^{\circ} \mathrm{S}-106.862654^{\circ} \mathrm{E}$ ), Kalibata area (coordinates: $06.25830^{\circ} \mathrm{S}-106.86040^{\circ} \mathrm{E}$ ), and Cawang area (coordinates; $06.28599^{\circ} \mathrm{S}-106.84717^{\circ} \mathrm{E}$ )

\section{Relative length of gut}

Measurement of the relative length of gut (RLG) is one of the methods used to distinguish fish based on the type of food they consume. It is determined by measuring the length of the digestive tract and body. Measurement of the relative length of the gut was calculated by the formula (Zuliani et al. 2016).

$$
R L G=\frac{G L}{T L}
$$

Where:

RLG : Relative Length of Gut

GL : Gut length

TL : Total length

The results from the measurement of the fish's RLG is distinguished in accordance with the following categorized values:

$<1$ : fish classified as carnivorous

1-3 : fish classified as omnivorous

$>3$ : fish classified as herbivorous
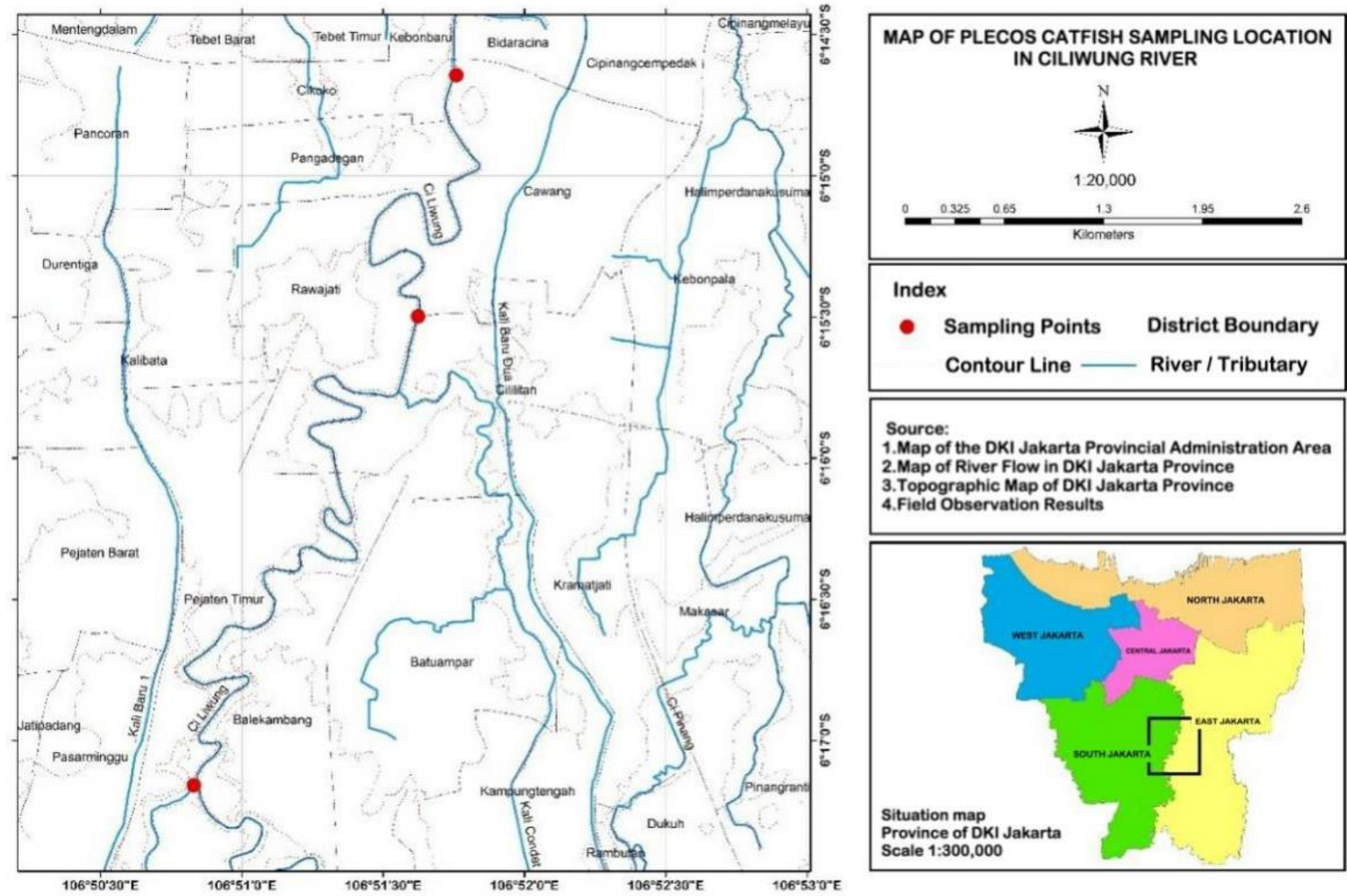

Figure 1. Three observation and sampling station along Condet-Cawang of Ciliwung River, Jakarta, Indonesia 


\section{Gut contents analysis}

The observation was carried out using the dilution of the gut contents, furthermore 2 drops were placed on the slide using a pipette. The samples were viewed under a binocular light microscope with magnification ranging from 100x, 400x, and 1000x using immersion oil (Tisasari et al. 2016; Widarmanto et al. 2019).

\section{Index of preponderance}

The Index of Preponderance was used to determine the various types of plecos fish food. It is used to analyze the percentage of the largest part of the organism consumed by combining the frequency of occurrence and volumetric method using the formula (Effendie 1997).

$$
I P=\frac{V i \times O i}{\sum(V i x O i)} \times 100 \%
$$

Where:

IP : Index of preponderance

$\mathrm{Vi}$ : Volume percentage of one type of food

Oi : Frequency percentage of one type of food occurrence

$$
\sum(\mathrm{Vi} \times \mathrm{Oi})=\text { the amount of } \mathrm{Vi} \times \text { Oi of all types of food }
$$

The volumetric method is conducted by comparing the types of organisms discovered in the channel with the volume of the liquid. However, this is obtained by calculating the average species consumed, based on the number of individuals (Hyslop 1980).

The following formula determines the volume percentage of one type of food.

$$
V i=\frac{\text { mumber of individuals in one type of food }}{\text { total of all types of food }} \times 100 \%
$$

Where:

Vi: Volume percentage of one type of food

The frequency of occurrence is a simple method of collecting data in accordance with the contents of the stomach, which consists of either a particular or various types of organisms (Hyslop, 1980). The percentage of the occurrence frequency of a particular type of food is determined by the formula

$O i=\frac{\text { the number of tracts that contain one type of food }}{\text { as well as the total mumber of the stomach that contains food }} \times 100 \%$

\section{Where:}

Oi: Occurrence frequency

Based on the percentage Index of Preponderance, the food is divided into three categories

IP> $40 \%$ main food

IP $4 \%-40 \%$ supplementary food

IP $<4 \%$ additional food

\section{Area of the diet niche}

The area of the diet niche is measured by understanding the distribution of individual organisms which is the source
(Colwell and Futuyma 1971), in addition, it is calculated based on the food consumed by fish using the Levin Index as follows:

$$
B=\left(\sum P i^{2}\right)^{-1}
$$

Where:

B : area of the diet niche

$\sum \mathrm{Pi}$ : total proportion of the i-th type of food consumed

Niche area

Standardisation is often used to express the diet niche area on a scale of 0 to 1 , however, it is obtained by dividing the Levin Index result by the number of food types consumed by the fish.

$$
B a=\frac{B-1}{n-1}
$$

Where:

$\mathrm{Ba}$ : Standardisation of levins' niche area

B : Niche area

$\mathrm{N}$ : Types of food consumed by fish

\section{Niche Overlap}

Niche overlap tends to occur when one or more organisms obtain food from a particular source using the following formula (Tresna et al. 2012).

$$
C h=\frac{2 \sum P i j . P i k}{\sum P i j^{2}+P i k^{2}}
$$

Where:

$\mathrm{C}_{\mathrm{H}}$ : Morisita Index

Pij, Pik: Proportion of species of i-th food organism used by two groups of $\mathrm{j}$-th fish and $\mathrm{k}$-th fish groups, in the same population

\section{Trophic level of an organism}

The trophic level of an organism is determined by counting the food fraction, which is obtained by the number of individuals per organism divided by the total number of individuals found in a particular group of fish with similar sizes. The trophic level is calculated with the following formula

$$
\text { Trophi }=1+\sum \text { DCij } x \text { Trophj }
$$

Troph-i : Trophic level i-th fish

DCij $\quad$ : $j$-th food fraction eaten by $i$

Troph-j : Trophic level fraction of $j$-th food

Based on the analysis, the trophic level is categorized into:

$2.00<$ Troph $<2.9$ category II fish as herbivore

$2.9<$ Troph $<3.7$ category III fish as carnivore

$3.7<$ Troph $<4.5$ category IV fish as carnivore 


\section{RESULTS AND DISCUSSION}

\section{Relative length of gut of Pterygoplichthys pardalis from Ciliwung River}

The results from the analysis of the relative length of gut (RLG) showed that the $P$. pardalis found in the Ciliwung River is included in the category of herbivorous fish. This is observed in the RLG values for each group of fish. The RLG from large to small fish groups are 10,98 $\mathrm{cm}, 11,17 \mathrm{~cm}$, and $17,49 \mathrm{~cm}$, respectively. Based on these values, $P$. pardalis is included in the category of RLG $>3$, as shown in Table 1.

The relative length of the gut is used as an indicator of the fish's feeding habits by comparing its length to the total length (Hyslop 1980; Delariva and Agostingo 2001; Lujan et al. 2012; Sampaio et al. 2013). According to research conducted by Tisasari, fish classified as herbivores usually have a total gut length of 5.9 times the body length (Tisasari, et al. 2016). Gut length is influenced by the fish's feeding patterns, which is observed in the relationship between the diet type and the gut length. Rhinelepis aspera has a significantly different gut length from Megalancistrus aculeatus because it has an entirely different diet type, however, both are species of Loricariidae (Delariva and Agostinho 2001).

Pterygoplichthys pardalis has a relatively long gut and is classified as herbivore however, and digestion lasts longer compared to fish in the other groups. The structure of the gut shows a strong adaptation to any diet type. Plecos fish diet type includes plant fragments, algae, and detritus. Algae and detritus are hard to digest and require longer mechanical power. The digestive process requires a large area for absorption, and this causes elongates the gut of the pleco (Armbruster 1998; Pound et al. 2011; Samat et al. 2016).

\section{Pterygoplichthys pardalis gut content in Ciliwung River}

The results from the analysis of the gut content of $P$. pardalis in the Ciliwung River showed that the various types of natural fish diet are grouped into Bacillariophyta, Chlorophyta, Cyanophyta, Euglenophyta, Amoebozoa, Dinoflagellata, and detritus (Table 2). Bacillariophyta is commonly found in the guts of plecos fish compared to the others. Conversely, these groups were discovered in as many as 59 genera. Generally, the Bacillariophyta group is found in sediments and substrates of both mild and strong currents (Genkal and Yarushina 2014; Genkal and Yarushina 2016). This is consistent with the feeding behavior of $P$. pardalis as a bottom feeder fish, because this group is a type of phytoplankton that is widely attached to sediments or substrates (Lujan et al. 2012; Genkal and Yarushina 2014; Genkal and Yarushina, 2016; Manna et al. 2020). The type of diet consumed by $P$. pardalis determines the feeding habits in the Ciliwung River.

The results from the gut content analysis, showed that the calculated percentage of natural diet consumed by $P$. pardalis is $82.03 \%$ Bacillariophyta. Therefore, it is the commonest type of natural diet, with Chlorophyta, Cyanophyta, Euglenophyta, Amoebozoa, Dinoflagellat $a$, and detritus at $12.17 \%, 3.74 \%, 1.19 \%, 0.28 \%, 0.68 \%$, and $0 \%$ (Figure 2).

Bacillariophyta is used as the primary source of the natural diet for the $P$. pardalis in the Ciliwung River because its habitat is at the bottom of the water, and it supports the characteristics of the mouth shape of plecos fish. According to the results from the study conducted by Pambudi in 2015, Bacillariophyta had the highest abundance compared to other divisions found in the river, followed by Chlorophyta (Pambudi et al. 2016).

Table 1. Relative length of gut in each fish category

\begin{tabular}{lccc}
\hline $\begin{array}{c}\text { Fish } \\
\text { categories }\end{array}$ & $\begin{array}{c}\text { Total length } \\
\text { (TL) }\end{array}$ & $\begin{array}{c}\text { Gut length } \\
\text { (GL) }\end{array}$ & $\begin{array}{c}\text { RLG } \\
\text { (cm) }\end{array}$ \\
\hline Large fish & 37.03 & 406.75 & 10.98 \\
Medium fish & 31.73 & 354.6 & 11.17 \\
Small fish & 21.64 & 378.53 & 17.49 \\
\hline
\end{tabular}

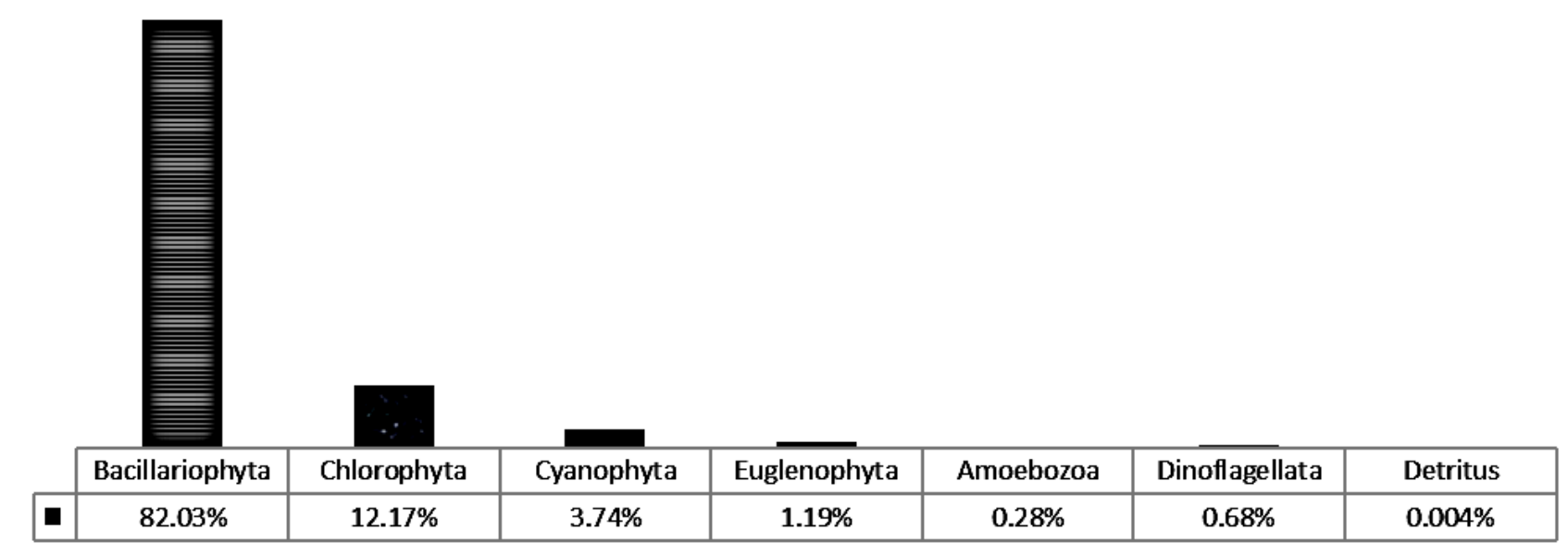

Figure 2. Percentage of Pterygoplichthys pardalis natural diet in the Ciliwung River, Jakarta, Indonesia based on gut content analysis 
Plecos consume phytoplankton, zooplankton and detritus as its main $(56.39 \%)$, supplementary $(36.94 \%)$ and additional $(6.67 \%)$ diets. These results are similar to those obtained in the previous studies which stated that pleco's main diet is Bacillariophyta, Chlorophyta, while Cyanophyta and Eugleophyta, Xanthophyta, Crustacea are additional diets (de Oliveira and Isaac 2013; Tisasari et al. 2016; Manna et al. 2020). The dissimilarities in the feeding habits of fishes tend to occur as a result of the differences in the availability of food utilized in its natural habitat. According to Effendi, fish's preference for diet is relative (Effendie 1997). Additionally, the distribution of food organisms, availability of natural diet, and physical conditions tend to influence their feeding habits (Garcia et al. 2018; Wei et al. 2018; Manna et al. 2020). Therefore, greater availability of food resources in the invaded habitats provided conditions that are conducive for the establishment of non-native species (Delariva and Agostinho 2001; Pound et al. 2011; Garcia et al. 2018).

\section{Pterygoplichthys pardalis Index Preponderance in Ciliwung River}

Index Preponderance (IP) explains the natural diet preferences of $P$. pardalis. Subsequently, IP based on the different types of fish groups shows similar diet preferences. The three groups of $P$. pardalis utilizes Bacillariophyta as its main natural food. The IP values of Bacillariophyta in the large, medium, and small fish groups are $86.70 \%, 78.66 \%$, and $81.11 \%$ (Figure 2). The preference of Bacillariophyta as the main natural diet for $P$. pardalis shows that its availability in the river is quite abundant. In addition, it is a type of microalgae that is epilithic, thereby making it is suitable for $P$. pardalis. Morphologically, $P$. pardalis has a triangular mouth shape suited towards the ventral that supports its feeding habits. This is due to the fact that it belongs to the group of algaefeeding fish that covers the bottom surface of the water. The morphology of the mouth's shape and structure allows the fish to erode food from hard surfaces and swallow soft sediments efficiently (Armbruster 2004; Samat et al. 2016; Manna et al. 2020).

The IP value of Chlorophyta in the large, medium, and small fish groups are $6.87 \%, 17.27 \%$, and $12.40 \%$, respectively. Conversely, the IP value of Cyanophyta in the large, medium, and small fish groups are 5.24\%. $1.87 \%$, and $4.11 \%$ (Figure 3 ). This showed that they are a type of natural supplementary diet for $P$. pardalis in the Ciliwung River. The abundance of Cyanophyta in the river ranks third after Bacillariophyta and Chlorophyta (Pambudi et al. 2016). This statement is supported by the results from the research which stated that Chlorophyta and Cyanophyta discovered in the guts of plecos fish in the Langat River, are relatively abundant in the habitat (Samat et al. 2016). Fishes generally adjust the food types to the size of their mouth openings, while the larger ones tend to consume more food (Zuluaga-Gomez et al. 2016; AguilarBetancourt et al. 2017; Winkler et al. 2017).

Table 2. The composition of the Pterygoplichthys pardalis natural diets in the Ciliwung River, Jakarta, Indonesia in accordance with gut content analysis.

\begin{tabular}{|c|c|}
\hline Category & Type \\
\hline Bacillariophyta & $\begin{array}{l}\text { Achnanthes sp., Achnantidhium sp., Amphipleura sp., Amphora sp., Aneumastus sp., Aulacoseira sp., Bacillaria } \\
\text { sp., Caloneis sp., Climacosphenia sp., Cocconeis sp., Craticula sp., Cyclotella sp., Cymbella sp., Cymbopleura sp., } \\
\text { Diadesmis sp., Diatoma sp., Diploneis sp., Encyonema sp., Entophysalis sp., Encyonopsis sp., Eolimna sp., } \\
\text { Eunotia sp., Ephitemia sp., Fallacia sp., Fragilaria sp., Frustulia sp., Geissleria sp., Gomphoneis sp., } \\
\text { Gomphonema sp., Grammatophora sp., Gyrosigma sp., Halamphora sp., Hantzschia sp., Luticola sp., Lemnicola } \\
\text { sp., Lyrella sp., Mastogloia sp., Melosira sp., Navicula sp., Neidium sp., Nepula sp., Nitzschia sp., Oedogonium } \\
\text { sp., Pinnularia sp., Placoneis sp., Planothidium sp., Prestauroneis sp., Rhoicospenia sp., Rivularia sp., } \\
\text { Rhopalodia sp., sellaphora sp., Stauroneis sp., Stenopterobia sp., Stephanodiscus sp., Surirella sp., Synedra sp., } \\
\text { Tabularia sp., Trybllionella sp., Ulnaria sp. }\end{array}$ \\
\hline Chlorophyta & $\begin{array}{l}\text { Ankistrodesmus sp., Asterococcus sp., Bulbochaete sp., Chlamydomonas sp., Chlorella sp., Chlorococcum sp., } \\
\text { Chlorococcus sp., Closterium sp., Choricystis sp., Coleastrum sp., Cosmarium sp., Crucigenia sp., Desmodesmus } \\
\text { serratus, Dictyochloropsis sp., Dictyococcus sp., Dictyosphaerium sp., Eudorina sp., Haematococcus sp., } \\
\text { Microspora sp., Monoraphidium sp., Oocystis sp., Oophila sp., Palmellopsis sp., Pediastrum sp., Planktosphaeria } \\
\text { sp., Scenedesmus sp., Selenastrum sp., Staurastrum sp., Steogclomium sp., Tetrastrum sp., Tetraedron sp., } \\
\text { Tetraspora sp., Volvox sp., Zygnema sp. }\end{array}$ \\
\hline Cyanophyta & $\begin{array}{l}\text { Anabaena sp., Aphanizomenon sp., Aphanocapsa sp., Aphanothece sp., Arthrospira sp., Chlorogloea sp., } \\
\text { Chroococcus sp., Gloeocapsa sp., Gleocapsopsis sp., Gloeocystis sp., Gloeothece sp., Gloeothichia sp., } \\
\text { Merismopedia sp., Neospongiococcum sp., Nostoc sp., Phormidium sp., Pseudocapsa sp., Pseudonabaena sp., } \\
\text { Rivularia sp., Synechococcus sp., Tychonema sp., }\end{array}$ \\
\hline Euglenophyta & Euglena sp., Lepocinclis sp., Phacus sp., Trachelomonas sp., Wailesella sp. \\
\hline Amoebozoa & Arcella sp., Centropyxis sp., Clypeolina sp., Pyxidicula sp., \\
\hline Dinoflagellata & Prorocentrum sp. \\
\hline Detritus & Meliola sp., Pestaliotiopsis sp. \\
\hline
\end{tabular}


The IP analysis obtained, showed that $P$. pardalis is included in the opportunist fish group because it is able to utilize the food available in the river. Plecos fish consumes phytoplankton as its main food $(56.39 \%)$, while zooplankton serves its supplementary food $(36.94 \%)$ and detritus as the additional food (6.67\%) (Tresna et al. 2012). However, $P$. pardalis consumes Bacillariophyta as its main food, Chlorophyta and Cyanophyta, as its supplementary foods, while Euglenophyta, Xanthophyta, Crustacea serves as additional foods (Mazzoni et al. 2010; Lujan et al. 2012; Samat et al. 2016; Tisasari et al. 2016; Manna et al. 2020). The differences in feeding habits of a particular type of fish tend to occur due to dissimilarities in the availability of food utilized in its natural habitat. Distribution of diet organisms, availability of food in the habitat, species of fish, and physical conditions influences feeding habits (de Oliveira and Isaac 2013; Perpetua et al. 2013; Sofarini, et al. 2019). It is also influenced by competition between individuals, predators, food chains from broad areas, and overlapping food niches (Effendi 2003; Pound et al. 2011; Manna et al. 2020).

\section{Feeding niches area}

The feeding niches area is a description of the proportion of the various food consumed by a particular type of fish (Mazzoni et al. 2010; Abilhoa et al. 2016; Hossain et al. 2018). The area of the feeding niche showed the size of the fish group that utilizes the available organisms as its natural diet source. In addition, it also utilizes aquatic resources (de Oliveira and Isaac 2013; Lopez-Rodriguez et al. 2019; Manna et al. 2020). Analysis of the feeding niche area is determined by the number and size of the different types of individuals in each group (Westerborn et al. 2018; Zhang et al. 2019). Standardization is conducted to obtain a broad variety of niches ranging from 0-1 intervals between variables that are not similar (Izzani 2012; Allgeier et al. 2017).

The results from the analysis of $P$. pardalis feeding niche area in the Ciliwung River in accordance with the group differences show that the large fish group has a larger niche area 42,87 compared to the other groups with standardization of 0.22 (Table 3 ). The huge value is expected because the fish are able to utilize the resources available in large quantities. However, this value is influenced by the number of the different types of food consumed by a particular group of fish with a relatively large niche area tends to have an increased number of species that are utilized as their food sources (Tresna et al. 2012; Pereira et al. 2016). It also implies that the fish group tends to evenly utilize all available resources in the aquatic environment as their natural diets. Besides, the size of the fish also affects the external diet niche. The feeding niche area for fishes is influenced by its length and size in their habitats (Armbruster 1998; Samat et al. 2016; LopezRodriguez et al. 2019; Manna et al. 2020).

The medium size fish group has a niche value of 36.01 with standardization of 0.19 (Table 3 ). This value is lower than that of the large fish group, and its decrease is due to the differences in the utilization of diet resources in the river. Therefore, fish with a lower niche area means that its group tends to be more selective in utilizing resources (Moody et al. 2019; Zhang et al. 2019).

The small size fish group has a lower niche area value of 16.78 with 0,07 standardization as shown in Table 3, because it uses food selectively. Fish that have a relatively small niche area uses less food types, and they specialize in utilizing diet resources (Sentosa and Satria, 2015; Garcia et al. 2018; Mwijage et al. 2018).

The joint use of available diet resources by the fish size groups tends to cause overlapping niches. Overlapping occurs when the food resources are shared by two or more types of fish (Sentosa and Satria 2015; Aguilar-Betancourt et al. 2017; Westerborn et al. 2018).

Table 3. The area of niches and standardization in each size category

\begin{tabular}{lccc}
\hline Category & Size & Niche area & Standardization \\
\hline Large fish & $340-415 \mathrm{~mm}$ & 42.87 & 0.22 \\
Medium fish & $264-339 \mathrm{~mm}$ & 36.01 & 0.19 \\
Small fish & $187-263 \mathrm{~mm}$ & 16.78 & 0.07 \\
\hline
\end{tabular}

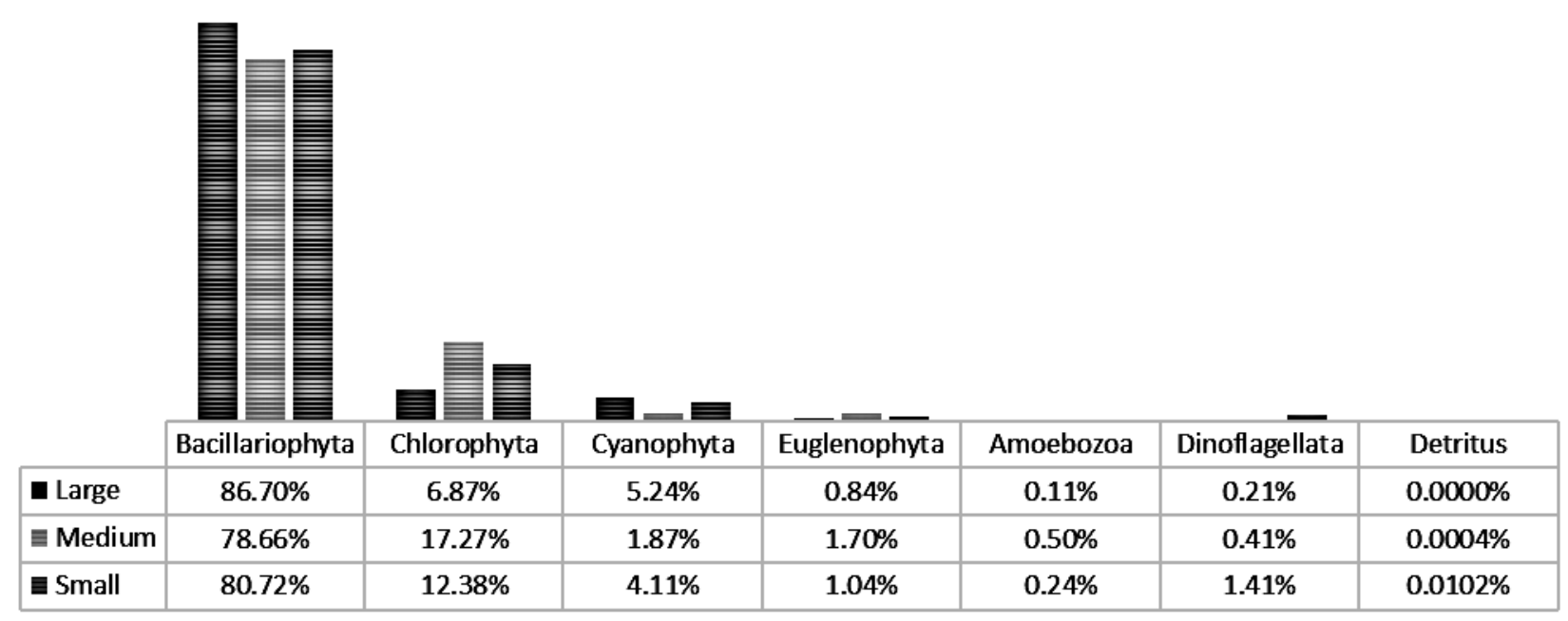


Figure 3. Index Preponderance of natural diet in each group of Pterygoplichthys pardalis in the Ciliwung River, Jakarta, Indonesia

Table 4. The intraspecific overlapping value between fish groups

\begin{tabular}{lccc}
\hline Category & Large & Medium & \multicolumn{1}{c}{ Small } \\
\hline Large & & 0.77 & 0.42 \\
Medium & & & 0.43 \\
Small & & & \\
\hline
\end{tabular}

The results from the analysis of overlapping niches showed that the relationship between the large and medium fish groups has a greater value (0.77) compared to that of other groups (Table 4). The value of overlapping niches implies the presence of organisms that are shared between the groups. It also shows the similarity in resource utilization of 0.77 . High overlapping values cause large and medium fish groups to compete for food.

The overlapping relationship between large and small fish groups is 0.42 , and that of the medium and small fish groups have a similarity value of 0.43 (Table 4). This means that the overlapping relationship between the medium and small groups, large and small groups, is lower compared to that between large and medium groups. The low value showed that there are differences in the organisms used. In addition, it is suspected that this reason led to a huge increase in the number of small and medium fish that was simultaneously discovered in the Kalibata area.

The value of overlapping feeding niches is approximately one (1). This means that similar resources are used which caused the 2 groups of fish to be highly competitive between two groups of fish. Overlapping values that are approximately zero (0) showed the differences in diet types between the two groups. Furthermore, overlapping of niches tends to occur when there are similarities in the diet types that are shared by two or more groups of fish (Izzani 2012; de Oliveira and Isaac 2013). The overlapping values of each group tend to trigger interactions or compete for food in the same location (Faria et al. 2018; Westerborn et al. 2018; Beuttner and Koch 2019).

\section{Pterygoplichthys pardalis trophic level in the Ciliwung River}

The results from the analysis of the trophic level of $P$. pardalis in the Ciliwung River show no difference in each of the groups. The value of $P$. pardalis trophic level in the river is 2.00 , which means that it is classified as group II herbivorous fish. This is in accordance with the trophic level category values $(2.00<$ trophic < 2.90). Herbivorous fish belong to group II because they eat phytoplankton, which is a type of food fraction at the trophic level of group I (Figure 4). Fish species classified as herbivores consume plants, phytoplankton, and detritus (Thompson et al. 2015; Samat et al. 2016; Manna et al. 2020). The analysis of trophic level supports Samat's statement that plecos fish have long guts and belong to the herbivorous group that feeds on algae and detritus besides, the environmental conditions are important for diet composition (Armbruster 2004; Samat et al. 2016; Manna et al. 2020).

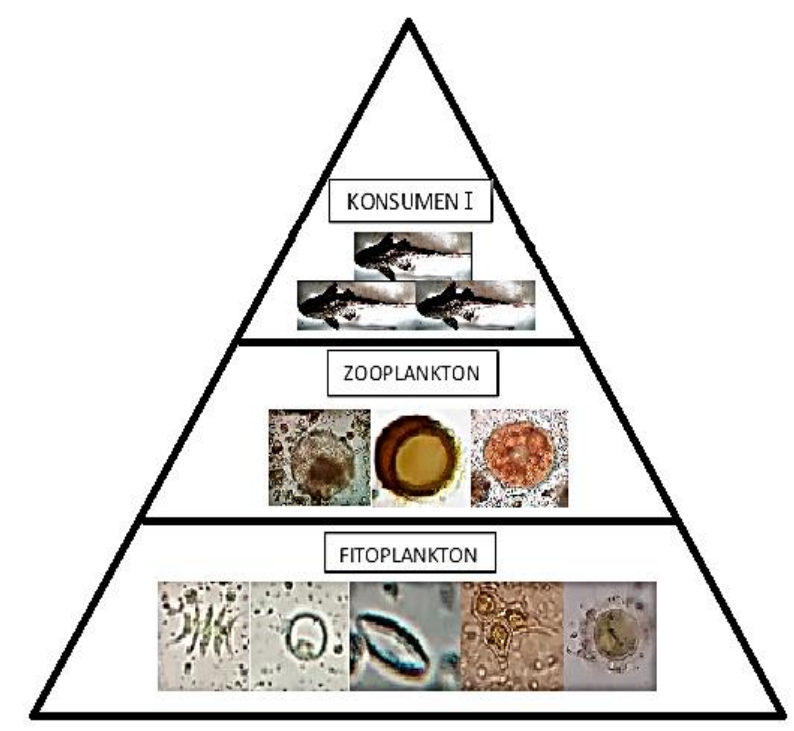

Figure 4. The trophic level of plecos fish in Ciliwung River, Jakarta, Indonesia

Pterygoplichthys pardalis is classified as a level I consumer and belongs to the herbivorous group, however, this causes it to compete with native fish for food. According to Tresna, Wader (Mystacoleucus marginatus) and silver rasbora (Rasbora argyrotaenia) are native fish from Cimanuk river, Garut subsequently, the composition of their natural diet consist of plankton, plant fragments, and detritus (Tresna et al. 2012). Native fish tend to compete with $P$. pardalis due to the composition of a natural diet in the feeding habitat. The ability of fish to adapt to environmental conditions is a determinant of its adaptation in the river (Eya et al. 2011; Sofarini et al. 2019; Manna et al. 2020). P. pardalis is able to survive in a polluted aquatic environment, however, it is also supported by morphological characters, such as an additional respiratory organ that functions as a respirator in poorly dissolved oxygen conditions (Armbruster 1998; Moroni 2015). These fish possess hard and prickly scales therefore there are no predators in the waters (Hadiaty 2011). The migration of $P$. pardalis in the waters of the Ciliwung River disrupted the food chain due to their feeding habits because they tend to feed on benthic algae and compete with native fish (Pound et al. 2011; Rao, 2017; Orfinger and Goodding 2018; Wei et al. 2018; Hossain et al. 2018).

In conclusion, the $P$. pardalis belongs to the group II $(2.00<$ trophies $<2.90)$ trophic level and is classified as a herbivorous fish in the ecosystem of the Ciliwung River. The composition of its natural diet consists of Bacillariophyta, Chlorophyta, Cyanophyta, Euglenophyta, Dinoflagellata, Amoebozoa, and detritus in the riverbed with Bacillariophyta as its main natural diet at a preference value of $82.03 \%$ (IP> 40\%). Meanwhile, its supplementary diet consists of $12.17 \%$ (IP 4-40\%) of Chlorophyta and additional diet (IP<40\%) of Cyanophyta (3.74\%), Euglenophyta (1.19\%), Amoebozoa (0.28\%), Dinoflagellata $(0.68 \%)$ and detritus $0.00 \%$. 


\section{ACKNOWLEDGEMENTS}

The authors are grateful to the Ministry of Research and Technology of Higher Education for the funds provided through the Directorate of Research and Community Service in 2018. The authors are also grateful to all those that contributed to this research.

\section{REFERENCES}

Abilhoa V, Valduga MO, de A Frehse F, Vitule JRS. 2016. Use of food resources and resource partitioning among five syntopic species of Hypostomus (Teleostei: Loricariidae) in an Atlantic Forest river in southern Brazil. Zoologia 33: 20160062. DOI: 10.1590/S19844689zool-20160062

Aguilar-Betancourt C, Gonzalez-Sanson G, Flores-Ortega JR, KosonovAceves D, Lucani-Ramirez G, Ruiz-Ramirez S, Padilla-Gutierrez SC, Curry RA. 2017. Comparative analysis of diet composition and it relation to morphological characteristics in juvenile fish of three lutjanid species in a Mexican Pacific coastal lagoon. Neotroph Ichthyol 15: e170056. DOI: 10.1590/1982-0224-20170056

Allgeier JE, Adam TC, Burkepile DE. 2017. The importance of individual and species-level traits for trophic niches among herbivorous coral reef fishes. Proc R Soc 284: 20170307. DOI: 10.1098/rspb.2017.0307

Armbruster J. 1998. Modification of digestive tract for holding air in Loricariidae in Scloloplacid catfishes. Copeia 3: 663-675.

Armbruster J. 2004. Phylogenetic relationships of the suckermouth armoured catfishes (Loricariidae) with emphasis on the Hypostominae and the Ancistrinae.. Zool J Linn Soc 14: 1-80.

Beuttner A, Koch C. 2019. Analysis of diet composition and morphological characters of the little-known Peruvian bush anole Polychrus peruvianus (Noble, 1924) in a northern Peruvian dry forest. Amphib Reptile Conserv 13: 111-121.

Carvalho F, Power M, Forsberg BR, Castello L, Martins EG, Freitas CEC 2017. Trophic Ecology of Arapaima sp. in a ria lake river-floodplain. Ecol Freshw Fish 2017: 1-10. DOI: 10.1111/eff.12341

Colwell RK, Futuyma DJ. 1971. On measurement of niche breadth and overlap. Ecol Soc Am 52: 567-576.

de Oliveira JS, Isaac VJ. 2013. Diet breadth and niche overlap between Hypostomus plecostomus (Linnaeus, 1758) and Hypostomus emarginatus (Valenciennes, 1840) (Siluriformes) in the Coaracy Nunes hydroelectric reservoir, Ferreira Gomes, Amapa-Brazil. Biota Amazonia 3: 116-125.

Delariva RL, Agostinho AA. 2001. Relationship between morphology and diets of six Neotropical Loricariids. J Fish Biol 58: 832-847.

Effendie M. 1997. Fisheries Biology. Yayasan Pustaka Nusantara. Yogyakarta. [Indonesian]

Effendi H. 2003. Review of Water Quality for Resource Management and the Aquatic Environment. Kanisius. Yogyakarta. [Indonesian]

Eya AAA, Lacuna DG, Espra AS. 2011. Gut content analysis of selected commercially important species of coral reef fish in the Southwest part of Iligan Bay, Northern Mindanao, Philippines. Publ Seto Mar Biol Lab 41: 35-49.

Faria FA, Albertoni EF, Bugoni L. 2018. Trophic niches and feeding relationship of shorebirds in southern Brazil. Aquat Ecol 52: 281-296. DOI: $10.1007 / \mathrm{s} 10452-018-9663-6$

Garcia DAZ, Vidotto-Magnoni AP, Orsi ML. 2018. Diet and feeding ecology of non-native fishes in lentic and lotic freshwater habitats. Aquat Invasions 13: 565-573. DOI: 10.3391/ai.2018.13.4.13

Genkal SI, Yarushina MI. 2014. Bacillariophyta in aquatic ecosystem of Arctic Tundra of Western Yamal (Hkarasaveiyakha River Basin, Rusia. Intl J Algae 16: 237-249.

Genkal SI, Yarushina MI. 2016. A study of flora of Bacillariophyta in water bodies and water courses of the Naduiyakha River Basin (Yamal Peninsula, Russia). Intl J Algae 18: 39-56.

Hadiaty RK. 2011. Study of Fish Diversity and The Lost of Fish Species of River Ciliwung and River Cisadane. Berita Biologi 10: 491-504. [Indonesian]

Harmoko Y. 2018. Microalgae of Bacillariophyta Division in Aur Lake Kabupaten Musi Rawas. J. Biologi Universitas Andalas 6: 30-35. [indonesian]
Hossain MY, Vadas RL, Ruiz-Carus R, Galib SM. 2018. Amazon sailfin catfish Pterygoplichthys pardalis (Loricariidae) in Bangladesh. Fishes 3: 14. DOI: $10.3390 /$ fishes3010014

Hyslop EJ. 1980. Stomach content analysis a review of methods and their application. J Fish Biol 17: 411-429.

Izzani N. 2012. Feeding habits tembang fish (Sardinella fimbiata Cuvier and Valenciennes 1847) from Sunda Strait that landed in PPP Labuan, Kabupaten Pandeglang, Banten. [Thesis]. Institut Pertanian Bogor, Bogor. [Indonesian]

Lopez-Rodriguez A, Silvana I, de Avila-SimaS, Stebniki S, Bastian R, Massaro MV, Pais J, Tesitore G, de Mello FT, D'Anatro A, Vidal N, Meerho M, Reynalte-Tataje AD, Zaniboni-Filho E, GonzalezBergonzoni I. 2019. Diets and trophic structure of fish assemblages in a large and unexplored subtropical river: The Uruguay River. Water 11: 1-26. DOI: 10.3390/w11071374

Lujan NK, Winemille KO, Armbruster JW. 2012. Trophic diversity in the evolution and community assembly of loricariid catfishes. BMC Evol Biol 12: 1-12.

Manna LR, Miranda JC, Rezende CF, Mazzoni R. 2020. Feeding strategy and morphology as indicators of habitat use and coexistence of two loricariid fishes from a Brazilian coastal stream. Biota Neotropica 20: e20190764. DOI: 10.1590/1676-0611-BN-2019-0764

Mazzoni R, Rezende CF, Manna LR. 2010. Feeding ecology of Hypostomus punctatus Valenciennes, 1840 (Osteichthyes, Loricariidae) in a costal stream from Southeast Brazil. Braz J Biol 70: 569-574.

Moody EK, Alda F, Capps KA, Puebla O, Turner BL. 2019. Trophic trait evolution explains variation in nutrient excretion stoichiometry among Panamanian armored catfishes (Loricariidae). Diversity, 11: 88. DOI: $10.3390 / \mathrm{d} 11060088$

Moroni FT, Ortega AC, Moroni RB, Mayag B, de Jesus RS, Lessi E. 2015. Limitation in decision Cntext for selection of Amazonian Armoured Catfish acari-bodo (Pterygoplichthys pardalis) as candidate species for aquaculture. Intl J Fish Aquacult 7: 142-150. DOI: $10.5897 /$ IJFA15.0480

Mwijage AP, Shilla DA, Machiwa JF. 2018. Differences in trophic resources and niches of two juvenile predatory species in three Pangani estuarine zones, Tanzania: stomach content and stable isotope approaches. J Biol Res Thessaloniki 25: 1-16. DOI: 10.1186/s40709-018-0084-4

Orfinger AB, Goodding DD. 2018. The global invasion of the suckermouth armored catfish genus Pterygoplichthus (Siluriformes: Loricariidae): Annotated list of species, distributional summary and assessment of impacts. Zool Stud 57: 1-16. DOI: 10.6620/ZS.2018.57-07.

Pambudi A, Priambodo TW, Noriko N, Basma. 2016. Ciliwung River phytoplankton diversity after the "Ciliwung Bersih" programme. J. Al Azhar Indonesia Seri Sains dan Teknologi 3: 204-211. [Indonesian]

Pereira PHC, dos Santos MVB, Lippi DL, de Paula Silva PH, Barros B.2016. Difference in the trophic structure of fish communities between artificial and natural habitats in tropical estuary. Mar Freshw Res. DOI: 10.1071/MF15326.

Perpetua MD, Gorospe JG, Torres MA, Demayo CG. 2013. Diet composition based on stomach content of the streaked spine foot (Siganus javus) from three coastal bays in Mindanao, Philippines. Intl J Bioflux Soc 5: 49-61.

Pound KL, Nowlin WH, Huffman DG, Bonner TH. 2011. Trophic ecology of a nonnative population of suckermouth catfish (Hypostomus plecostomus) in a central Texas spring-fed stream. Environ Biol Fish 90: 277-285. DOI 10.1007/s10641-010-9741-7

Rao RK, Sunchu V. 2017. A Report on Pterygoplychthys pardalis Amazon Sailfin Suckermouth Catfishes in Freshwater tanks at Telangana State, India. Intl J Fish Aquat Stud 5: 249-254.

Samat A, Yusoff FM, Nor SM, Ghaffar MS, Arshad A. 2016. Dietary analysis of an introduced fish, Pterygoplichthys pardalis from Sungai Langat, Selangor, Peninsular Malaysia. Malayan Nature J 68: 241246.

Sampaio ALA, Pagotto JPA, Goulart E. 2013. Relationships between morphology, diet, and spatial distribution: testing the effects of intra and interspecific morphological variations on the patterns of resource use in two Neotropical Cichlids. Neotrop Ichthyol 11: 351-360.

Sentosa AA, Satria H. 2015. Feeding habits on several kind of fish in Rawa Kaiza Sungai Kumbe Kabupaten Merauke, Papua. Limnotek 22: 32-41. 
$\begin{array}{ccccc}\text { Sharpe } & \text { S. } & 2016 . & \text { Fish } & \text { mouth } \\ \text { http://freshaquarium.about.com/od/termsandtables/tp/Fish-Mouth- }\end{array}$ http://freshaq.htm

Sofarini D, Herawati EY, Mahmudi M, Hertika AMS, Arfiati D, Musa M, Amin M, Supriharyono. 2019. Analysis of stomach content of piscivorous fishes caught in Danau Panggang Peatland, South Kalimantan, Indonesia. Biodiversitas 20: 3788-3793. DOI: 10.13057/biodiv/d201243.

Thompson PL, Davies JT, Gonzales A. 2015. Ecosystem functions across trophic levels are linked to functional and phylogenetic diversity. PLoS ONE 10: 1-19. DOI: 10.1371/journal.pone.0117595

Tisasari M, Efizon D, Pulungan CP. 2016. Stomach content analysis of Pterygoplichthys pardalis from the Air Hitam River, Payung Sekaki District, Riau Province. Jurnal Online Mahasiswa Fakultas Ilmu Perikanan dan Kelautan Universitas Riau 3: 1-14.

Tresna LK, Dhahiyat Y, Herawati T. 2012. Feeding habits and niche area of fish in Cimanuk River upstream Kabupaten Garut, Jawa Barat. Jurnal Perikanan dan Kelautan 3: 163-174. [Indonesian]

Wei H, Chaichana R, Liu F, Luo D, Qian Y, Gu D, Mu X, Xu M, Hu Y. 2018. Nutrient enrichment alters life-history traits of non-native fish Pterygoplichthys spp. in sub-tropical rivers. Aquat Invas 13: 421-432. DOI: 10.3391/ai.2018.13.3.09.

Westerborn M, Lappalainen A. Mustonen O, Norkko A. 2018. Trophic overlap between expanding and contracting fish predators in a range margin undergoing change. Sci Rep 8: 7895. DOI: 10.1038/s41598018-25745-6.
Widarmanto N, Haeruddin H, Purnomo PW. 2019. Food habits, niche breath and trophic level on fish community in Kaliwingi Estuary Brebes District. Bawal 11: 69-78.

Winkler NS, Paz-Goicoechea M, Lamb RW, Perez-Matus A. 2017. Diet reveals link between morphology and foraging in a cryptic temperate reef fish. Ecol Evol 7: 11124-11134. DOI: 10.1002/ece3.3604.

Zainordin AF, Hamid SA. 2017. Determination of trophic structure in selected freshwater ecosystems by using stable isotope analysis. Trop Life Sci Res 28: 9-29.

Zardo EL, Behr ER. 2016. Trophic ecology of Loricariichthys melanocheilus Reis \& Pereira, 2000. Acta Scientiarum 38: 67-76. DOI: 10.4025/actascibiolsci.v38i1.26384.

Zhang M, Wang Y, Gu B, Li Y, Zhu W, Zhang L, Yang L, Li X. 2019. Resources utilization and trophic niche between silver carp and bighead carp in two mesotrophic deep reservoirs. Freshw Ecol 34: 199-212. DOI: 10.1080/02705060.2018.1560368.

Zuliani Z, Muchlisin ZA, Nurfadillah N. 2016. Food habits and weightlength relationship garfish in Alur Hitam River Kecamatan Bendahara Kabupaten Aceh Tamiang. Jurnal Ilmiah Mahasiswa Kelautan dan Perikanan Unsyiah 1: 12-24. [Indonesian]

Zuluaga-Gomez MA, Fitzgerald DB, Giarrizzo T, Winemiller KO. 2016. Morphologic and trophic diversity of fish assemblages in rapids of the Xingu River, a major Amazon tributary and region of endemism. Environ Biol Fish. DOI 10.1007/s10641-016-0506-9. 